товариством «Просвіта» і ін. про прийом учнів до Малої духовної семінарії. ЦДІАЛ, ф. 451, оп. 1, спр. 378, арк. 9.

12. Листування Малої духовної семінарії в м. Львові з Грекокатолицьким митрополичим ординаріатом там же про виділення грошей на господарські потреби. ЦДІАЛ, ф. 451, оп. 1, спр. 372, арк. 7-8.

13. Протоколи, звіти, листування та ін. документи про діяльність Малої духовної семінарії в м. Львові за 1938-1939 навчальний рік. ЦДІАЛ, ф. 451, оп. 1, спр. 369, арк. 24.

DOI https://doi.org/10.30525/978-9934-588-91-4-26

\title{
СТУДЕНТКИ ПОЛЬСЬКОЇ НАЦІОНАЛЬНОСТІ В КИЇВСЬКОМУ КОМЕРЦЙНОМУ ІНСТИТУТІ: МОВОЮ НЕВІДОМИХ АРХІВНИХ ДОКУМЕНТІВ
}

\author{
Чуткий А. I. \\ доктор історичних наук, доцент, \\ доцент кафедри давньої та нової історії Украӥни \\ Київського національного університету імені Тараса Шевченка \\ м. Київ, Україна
}

Національний чинник є важливою складовою, що визначає життя будь-якої держави світу та міжнародні відносини. Особливо потужним він став 3 середини XIX ст., а в європейському просторі - на сході континенту [12]. Серед них чільне місце належало й польському національно-визвольному руху, що посилився на початку XX ст. (коли поляки за словами Н. Дейвіса «стали більш польськими») і призвів до відновлення польської державності [13, с. 720-738].

Другим таким чинником є гендерний, зокрема дослідження ролі жіноцтва, що безумовно $є$ дуже важливим для повноцінного історичного дискурсу.

В цій статті я поєднав обидва ці чинники в контексті вивчення невідомого аспекту з історії польської громади України початку XX ст. здобуття польськими дівчатами вищої освіти у Київському комерційному інституті. Справа вивчається на основі матеріалів 3 архіву цього інституту, що вперше вводяться до наукового обігу.

Встановлено, що у Київському комерційному інституті поляки становили третю за чисельністю етнічну групу серед його студентів [14]. Також в інституті діяли дві організації, що об'єднували вихідців із Польщі - Варшавське земляцтво та Польський гурток [14]. 
Закономірно, що більшість студентів-поляків інституту становили особи чоловічої статі. Проте було виявлено й ряд представниць прекрасної статі, сам факт здобуття вищої економічної освіти якими є красномовним. Найбільше з виявлених студенток-польок походили з Поділля (4), а також з Київщини (4), що узгоджується зі значною часткою поляків в населенні саме цих регіонів України. Ще по одній походили 3 Волині та Одеси і водночас жодної - з Лівобережжя, що теж узгоджується з етнічною ситуацію того часу.

Перша зі студенток-польок, чия особова справа була виявлена в архіві інституту, - Стефанія Братковська народилася 1887 р. в родині польських дворян з Поділля [8, арк. 4], середню освіту здобула спочатку у Вінницькій жіночій гімназії, а в 1907-1908 рр. в приватній гімназії Києва [8, арк. 2а]. В серпні 1908 р. вона вступила на навчання до ККІ, який закінчила влітку 1914 р. [8, арк. 1, 16]. Щоправда, випускні іспити вона склала аж восени 1916 р., що можна пояснити ускладненнями викликаними початком війни, а потому (навесні 1915 р.) і ії важкою хворобою (запалення легень) [8, арк. 27, 32, 35]. Також варто зазначити, що попри своє дворянське походження, С. Братковська в період навчання в інституті теж мусила прохати про звільнення від плати за навчання. При цьому повідомила, що іiі місячні витрати складали 25 руб. (з яких 10 руб. йшло на плату за орендовану квартиру і 6,5 руб. за харчування) [8, арк. 90]. Ця сума, відповідного до проведеного опитування серед київського студентства, належало до найнижчої суми витрат 3-поміж них [11, арк. 20].

Наступна - Францишка Журавська - народилась в 1890 р. у м. Махнівці на Поділлі в родині польських дворян, середню освіту здобула в Білій Церкві (1900-1907рр.) [2, арк. 3, 1]. Заяву про вступ до Київського комерційного інституту вона подала в 1908 р., але до навчання не приступила.

3 Поділля походила й ще одна представниця польської громади Едуарда-Марія Красницька, але вона народилась в родині австрійського підданого [9, арк. 35, 42], що підтверджує факт контактів поляків і попри роздільність Польщі до 1918 р. державними кордонами державпоневолювачів. Середню освіту вона здобула в Маріїнській Харківській жіночій гімназії та в приватній жіночій гімназії в Києві [9, арк. 3-4, 21]. В 1908 р. вона вступила на навчання до Київського комерційного інституту [9, арк. 1]. В 1911 р. М. Красницька вирушила в закордонне відродження (до Швейцарії та Франції) [9, арк. 14]. А восени 1912 р. прохала про звільнення від плати за навчання зазначивши, що «уроками» (репетиторством) заробляла 25 руб. на місяць 3 яких 10 руб. витрачала на знімання квартири та 8 руб. на харчування, при цьому батько працював на цукровому заводі в Чернігівській губернії і навчались ще 2 братів [9, арк. 18а]. У червні 1913 р. вона закінчила інститут 
та здобула диплом кандидата економічних наук 2-го розряду [9, арк. 23], тобто без відзнаки.

Марія Дурач народилась в 1890 р. в родині гайсинських міщан римо-католицького віросповідання в с. Доброму, а охрещена в Умані [5, арк. 1]. У 1908 р. закінчила Уманську жіночу гімназію [5, арк. 2], а мешкала в Гайсині, тобто на Поділлі [5, арк. 6, 7]. 3 грудня 1909 по 1913 р. вона навчалась в Київському комерційному інституті [5, арк. 5, 4].

Ірена Пласковицька народилась в родині польських дворян у Києві в 1896 р., середню о світу здобула в приватній гімназії Києва [3, арк. 12, 10]. До інституту вступила у 1912 р. [3, арк. 9]. 3 початком Першої світової війни пішла працювати сестрою милосердя в Польському комітеті санітарної допомоги і не змогла поїхати за інститутом до Саратова «внаслідок обставин воєнного часу» [3, арк. 5], що можна пояснити дорожнечею в переповненому евакуйованими Саратові. 10 вересня 1918 р. вона прохала про звільнення від плати за поточний семестр, оскільки перебувала тоді в Смоленській губернії, з якої не могла виїхати «унаслідок зробленими більшовиками перешкод до мого приїзду до Києва» [3, арк. 3]. Попри це 10 серпня 1918 р. вона змогла вступити в Києві у шлюб (в костелі св. Олександра, із зазначенням, що вона та іï чоловік були прихожанами цього костелу) [3, арк. 2]. Але оскільки до навчання не повернулась, то можна припускати, що подружнє життя вплинуло на це.

Друга полька, що походила 3 Київщини - Яніна ВойтковічПавлович народилась 1891 р. в родині польських дворян у Білій Церкві, де в 1901 - 1909 pр. здобула середню освіту [4, арк. 12, 4] і в 1910 p. вступила до ККІ [4, арк. 4]. Але оскільки на цьому ії особова справа уривається, то, вочевидь, до навчання вона не приступила.

Юзефа Мацишевська (Братковська) народилась в 1887 р. у с. Чорнорудки Київської губернії в родині польських міщан із Бердичіва, середню освіту здобула спочатку «у приватному пансіоні у Варшаві», а потому в Київській Фундуклеївській гімназії [10, арк. 21, 3]. У 1906-1913 pp. навчалась в Київському комерційному інституті (тобто 3 моменту його заснування), але диплом отримала аж в квітні 1918 р. [10, арк. 85, 8, 21]. Також у 1910 р. вступила у шлюб з польським дворянином Е. Братковським родом із Києва, взявши прізвище останнього [10, арк. 6].

Наступна представниця польської громади Києва, котра вчилась у комерційному інституті - Яніна Стржельбицька народилась 1890 р. в родині спадкових почесних громадян у Києві, де здобула в 1908 р. середню освіту [7, арк. 4, 7] й одразу вступила до Київського комерційного інституту. Восени 1911 р. вона прохала про зменшення плати за навчання на половину (зазначивши, що живе і харчується у матері, а джерелом доходів назвала 15 руб. від «уроків»); а в 1912 р. прохала повністю звільнити від плати за навчання (зазначивши про себе, що харчується вдома і підробітків немає) [7, арк. 12-13, 15, 17]. У вересні 
1912 р. вона вступила у шлюб, оформлений у київському костелі [7, арк. 2]. Оскільки після цього вона припинила навчання, то можна ув'язувати цю подію з їі вступом у шлюб.

Ядвіга-Слена Лісовська народилася в 1889 р. у родині дворянина й відставного офіцера в Житомирі, де 1906 р. закінчила гімназію [6, арк. 17, 11]. У 1912 р. вона вступила на навчання до комерційного інституту. Але восени 1913 р. вступила у шлюб [6, арк. 4, 6, 7] і незабаром (1914 р.) теж залишила навчання.

Єлена Висоцька вступила до комерційного інституту в 1910 р., зазначивши, що за національністю вона полька, католицького віросповідання, 3 купецької родини [1, арк. 6 зв.]. Середню освіту здобула у Фундуклеївській гімназії в Києві. 3 копії метричної виписки слідує, що вона народилась в Одесі і що іiі батько належав до одеських купців [1, арк. 12]. В інституті вона провчилась недовго і вибула 3 невідомих причин.

Таким чином, бачимо, що поляки на початку XX ст. характеризувались відповідністю новим віянням, властивим для провідних країн того часу - польське жіноцтво теж прагнуло до активної позиції у житті. Тому йшло здобувати вищу економічну освіту. Бачимо, що найбільше поляків походило з Правобережної України. Також засвідчується значна частка бідної шляхти, що теж радикалізувало їх опозиційність щодо Російської імперії.

Щодо їх студентського життя, засвідчується негативний вплив бідності. Головним джерелом підробітків виступало репетиторство, але життєвий рівень багатьох був незадовільним. Тож чимало осіб мусили кидати навчання, також і через початок сімейного життя або політичні катаклізми початку XX ст.

\section{Література:}

1. Державний архів м. Києва. Ф. 153. Оп. 3. Спр. 664, 15 арк.

2. Державний архів м. Києва. Ф. 153. Оп. 3. Спр. 1305, 3 арк.

3. Державний архів м. Києва. Ф. 153. Оп. 5. Спр. 6297, 1-24 арк.

4. Державний архів м. Києва. Ф. 153. Оп. 6. Спр. 223, 12 арк.

5. Державний архів м. Києва. Ф. 153. Оп. 6. Спр. 403, 10 арк.

6. Державний архів м. Києва. Ф. 153. Оп. 6. Спр. 787, 25 арк.

7. Державний архів м. Києва. Ф. 153. Оп. 6. Спр. 1230, 25 арк.

8. Державний архів м. Києва. Ф. 153. Оп. 7. Спр. 112, 92 арк.

9. Державний архів м. Києва. Ф. 153. Оп. 7. Спр. 852, 89 арк.

10. Державний архів м. Києва. Ф. 153. Оп. 7. Спр. 1262, 86 арк.

11. Державний архів м. Києва. Ф. 153. Оп. 9. Ч. ІІ. Спр. 66, 20 арк.

12. Граціозі А. Війна і революція в Свропі. Київ: Основи, 2005. 350 с.

13. Дейвіс Н. Боже ігрище: історія Польщі. Київ: Основи, 2008. $1080 \mathrm{c}$. 
14. Чуткий А.І. Невідомий аспект з історії польської громади Києва початку XX ст.: Польський гурток та Варшавське земляцтво у Київському комерційному інституті (1908-1914 pp.). Europa Orientalis. Studia z dziejow Europy Wschodniej I panstw Baltyckich. 2015. № 6. S. 11-34.

DOI https://doi.org/10.30525/978-9934-588-91-4-27

\title{
ДЕНІКІНСЬКИЙ РЕЖИМ НА ПІВДНІ УКРАЇНИ 1918-1920 РР. У ДИСЕРТАЦЙНИХ РОБОТАХ СУЧАСНИХ УКРАЇНСЬКИХ ІСТОРИКІВ
}

\author{
Шапорда В. А. \\ методист відділення морського та річкового транспорту \\ Державного вищого навчального закладу \\ «Миколаївський політехнічний коледж» \\ м. Миколаїв, Украӥна
}

Одними із важливих джерел для вивчення режиму А. І. Денікіна на Півдні України у 1918-1920 рр. є дисертаційні дослідження, тому важливо проаналізувати дисертації українських істориків 3 даної теми. У 1996 р. захистив кандидатську дисертацію з історіографії проблем російського білого руху в Україні, яка в 1998 р. вийшла окремою монографією, О. В. Козерод [1, 2]. Автор поставив собі завданням узагальнити й проаналізувати історію досліджень білого руху в Україні. На жаль, назва праці не зовсім відповідає предмету дослідження. У роботі спостерігається постійне перемикання уваги на історіографію проблеми боротьби з білим рухом, а подекуди й просто на громадянську війну. Аспект боротьби селян Півдня України 3 денікінським режимом розглядає у дисертації Ю.В. Котляр [3], а окремі епізоди перших сутичок військ Директорії УНР з російськими добровольцями в Одесі висвітлює у своїй дисертації В.А. Пархоменко [4]. У 2005 р. захистив кандидатську дисертацію по історії білого руху в Україні В.О. Крупина [5], а у 2006 р. - Я.В. Штанько [6]. В їх роботах розглядається процес зародження та функціонування білого руху, його ідеологічна платформа та внутрішня політика, поширення на теренах України, боротьба з радянською владою та стосунки 3 українськими національними урядами.

У 2009 р. була захищена дисертація доктора історичних наук С.В. Корновенка [7]. Фактологічний матеріал, теоретичні положення, висновки й узагальнення, які містяться у цій роботі, суттєво розширюють сучасні знання 3 історії країн Центральної та Південно- 